\title{
Revidovati Veltruského
}

\author{
Herta Schmid
}

Zdá se, že v naší době je otázka vztahu mezi dramatem a divadlem definitivně vyřešena. Díky dlouhému období tzv. režisérského divadla přestal být dramatický text považován za umělecké dílo hodné úcty. Ještě škodlivější je popírání rozdílu mezi dramatem a epickým dílem ze strany moderních teoretiků. Jiř́ího Veltruského zvláště znepokojuje jejich zvyk používat při popisu dramatu terminologii vypůjčenou z naratologie. ${ }^{1}$ Jeho výzkum vychází z neustálých úvah o charakteristických rysech dvou uměleckých oblastí, dramatu a divadla. Jeho úvahy vedou k doporučení, aby se tyto umělecké oblasti opět spojily, ale nikoliv pod hlavičkou literatury jako v době Hegelově, ani pod nadvládou neliterárních umění jako během historické avantgardy, ale spíše tím, že si jasně uvědomíme, v čem se liší.

Pokud by byl takový postoj pouze výsledkem osobních preferencí, mohl by být zamítnut jako názor donkichotského samotáře. Veltruský si je vědom, že musí pro svůj názor předložit přesvědčivé argumenty. Pro pátrání po argumentech by bylo možno použít motto, které formuloval Oskar Walzel při rozepř́ich o dramatech Williama Shakespeara: dobré věci vyčnívají ze své doby i místa. K uznání dojdou v průběhu staletí. ${ }^{2}$

Ony „dobré věci“, které podporují Veltruského teorii, jsou dvojího druhu. Zaprvé našel spřízněnou osobnost v Otakaru Zichovi, předchůdci Jana Mukařovského na pozici vedoucího katedry estetiky Univerzity Karlovy v Praze. Jeho Estetika dramatického uměni: Teoretická dramaturgie, vydaná v roce 1931, se setkala s velkou kritikou mimo jiné proto, že autor odmítl moderní experimentální divadlo ve prospěch staromódního realismu. V jeho př́ípadě nešlo o neznalost či projev individuálního vkusu, ale spíše

1 Ve své práci „Drama jako literární dílo a představení“ píše: „Zichovo očividně absurdní začlenění dramatické literatury do epického druhu už bylo od té doby zase vzkř́íšeno, aspoň implicitně, v nedávných studiích, které se snaží popisovat drama pomocí tzv. naratologie“ (VELTRUSKÝ 1985: 16, česky in VELTRUSKÝ 1994: 98).

2 Srov. (WALZEL 1968). Kritizuje Gustava Freytaga (vrátím se k němu později) kvưli využívání neadekvátních norem při posuzování Shakespeara. Walzel, který se držel formalistické estetiky Johanna Friedricha Herbarta, aplikoval komparativní analytické metody v literatuře. Barokní malî́ství a architektura mu pomohly objevit i barokní prvky v Shakespearově využití prostoru a času. Baroko a renesance nepředstavují pouze charakteristické rysy historických epoch, ale také světové umělecké styly. 
o soustředění zájmu na oblast experimentální estetiky. ${ }^{3}$ Ve své studii se snažím odhalit, co dobrého našel Veltruský u Zicha, kromě Zichovy zdánlivě tvrdohlavé kritiky hlavního proudu myšlení, což se podobá zdánlivému donkichotismu u Veltruského. Druhou podporu nalezl u svého univerzitního učitele Jana Mukařovského, který dostal od Pražského lingvistického kroužku úkol rozvinout strukturální teorii literatury. Existuje samozřejmě mnoho dalších vlivů, ale jak se zdá, celoživotní vnitřní spor Veltruského se Zichem a Mukařovským leží v samém centru jeho výzkumu. ${ }^{4}$

Ve sporech mezi těmito osobnostmi jsou argumentace jednoho využity proti druhému a naopak. Veltruský využívá Mukařovského výzkum dialogu a monologu jako argument proti Zichově hlavní tezi, podle níž napsané dramatické dílo není samostatně stojící umělecké dílo, ale jeho dokončení závisí na divadelním provedení. Na druhé straně Zichovy znalosti struktury dramatické zápletky částečně pomáhají Veltruskému vyjádřit nesouhlas s Mukařovského odstraněním principu dialogu v divadle. Dramatická zápletka však pro něj zůstává otevřeným tématem. V určitých fázích Veltruský přiznává, že v př́ípadě výše zmíněných problémů nenachází žádné uspokojivé řešení. Myslím, že v př́padě dramatické zápletky je v jeho díle patrná souvislost s analytickou metodou tzv. sémantického gesta, kterou vytvořil Jan Mukařovský.

\section{Dialog a monolog jako řečové formy a jako literární žánry}

V roce 1940 Mukařovský vydal svůj slavný článek „Dialog a monolog“. Nejedná se o studii z oblasti literárních žánrů, ale z oblasti každodenní komunikace. Výchozími body jsou složky komunikace: dva nebo více partnerů přítomných ve stejné vnější situaci a společný předmět jejich řeči nastavují podmínky bud' pro dialog, nebo monolog. Předpokladem dialogické komunikace je právo kteréhokoli partnera převzít roli aktivního mluvčího. V monologu je aktivním mluvčím pouze jeden partner, zatímco druhý zůstává pasivním posluchačem. Tuto studii proslavila především analýza sémantiky dialogu a monologu. Dialogickou sémantiku tvoří vzájemné vstupy dvou (nebo více) kontextů, které jsou vyjádřeny replikami všech účastníků. Monologickou sémantiku tvoří pouze nepřetržitý vývoj kontextu mluvčího. Díky tomu je vnitřní sémantická struktura dialogu komplexnější než sémantika monologu. Analýza komplexnosti dialogu vyžaduje specifické lingvistické nástroje, které do té doby téměř neexistovaly, protože dialogy i monology byly považovány za vnější stylistické formy.

Cílem studie „Dialog a monolog“ je najít dialogické podžánry a přechody mezi dialogem a monologem. ${ }^{5}$ To byl lingvistický trend, který v téže době v Rusku propagoval například Michail Bachtin. Tento trend byl často spojován s psychologickým výzkumem

3 Zich aplikuje psychologii Gustava Theodora Fechnera na jeho teorii, později zvanou pre-sémiotika. Viz (ZICH 1986 [1931]: 93, také 350, pozn. 93.) Poznámky a komentáře k tomuto vydání napsali Ivo Osolsobě a Miroslav Procházka.

4 Miroslav Procházka (1994) si rovněž uvědomuje dlouhodobý vliv Zicha a Mukařovského na Veltruského.

5 Psychologické přechody mezi dialogem a monologem jsou analyzovány ve čtvrté části „Dialogu a monologu“ s podtitulem „Dialog v monologu a monolog v dialogu“. 
jazyka. Jeho vliv můžeme spatřovat i ve způsobu, jakým Mukařovský používá termín psychologická situace pro vnitřní situaci všech partnerů a pro vzájemný vztah mezi nimi. Dalším časově ohraničeným tématem je problém genetické priority monologu nebo dialogu v dějinách lidského jazyka a v individuálním vědomí či podvědomí. Mukařovský se zmíněnému tématu věnuje ve své studii z roku 1940 „O jazyce básnickém“. I zde, stejně jako ve svých předchozích textech, jasně rozlišuje mezi lyrikou a epikou jako dvěma monologickými žánry, zatímco drama považuje za žánr výhradně dialogický.

Jak jsem již uvedla, nezabývá se pozoruhodná studie „Dialog a monolog“ pouze specifiky dramatického žánru. Čtenář si může v Mukařovského spisech všimnout obecného přehlížení dramatu a upřednostňování divadla. Možným důvodem pro opomíjení dramatu může být vliv Otakara Zicha, který nejenže vyřadil drama ze systému literárních žánrů, ale rovněž vyhlásil, že dramatický žánr historicky vznikl z epiky. ${ }^{6}$ Uvedená definice představovala pro Mukařovského metodologický problém, protože sám odvozoval literární žánry z komunikativních funkcí v díle Karla Bühlera Organon Model. Jak víme, spojuje tento model vnější situaci s poznávací funkcí (Darstellung), vztah mezi mluvčím a situací s výrazovou funkcí (Ausdruck) $)^{7}$ a vztah mezi posluchačem a situací s funkcí výzvovou (Appell). Je poučné pozorovat, jak Mukařovský pracuje s funkčním modelem: sdělovací funkci přibližuje epice, výrazovou k lyrice, zatímco pojmy výzva a drama, které by měly být podle této distribuční logiky propojeny, ve svých úvahách zcela vynechal. ${ }^{8}$ Důvodem Mukařovského mlčení byl pravděpodobně jeho názor, že výzva neplní nezbytně dialogickou funkci. Jeho přístup k otázce lingvistických funkcí a literárních žánrů vedl k jistému dilematu.

Zdá se, že Veltruský si Mukařovského dilematu povšiml. Jeho vlastní přístup k Bühlerově modelu nabízí řešení. Místo přímého spojení jedné lingvistické funkce s jedním literárním žánrem se nejdříve zamýšlí nad tím, co Bühler chápal pod termínem Darstellung. Podle Veltruského byla Bühlerova teorie jazyka v souladu s tradičním přesvědčením, že jazyk slouží především jako epistemologický nástroj. Proto funkce Darstellung souvisí s poznáváním. Funkce Ausdruck má formulovat myšlenky mluvčího a funkce Appell označuje přání mluvčího poslechnout si myšlenky partnera v reakci na jeho myšlenky. Jazyk, který je považován za epistemologický nástroj, se soustředí na Darstellung, jeho myslící subjekt je považován za všeobecnou mysl, jejíž součástí je mysl každého jednotlivce. Dvě funkce Ausdruck a Appell ukazují, jak myšlení konkrétních lidských bytostí přistupuje k univerzálně platným myšlenkám nebo idejím. Zapojení individuálního poznávacího jednání může být doprovázeno osobními pocity, ale emocionální prvky nesmí zastínit obsah poznání, jak zdůrazňuje Veltruský. Moderní teorie, které považují jazyk za prostředek komunikace namísto poznání, definují výraz a výzvu jako hlavní

\footnotetext{
$6 \quad$ Viz též pozn. 1.

7 Bühler hovoří o různých označeních pro Ausdruck a Appell, mezi jinými i o termínech Kundgabe/Kundnahme Edmunda Husserla. Tyto varianty souvisí s problémem funkce a znaku, kterému se zde nebudu věnovat. Proto dále budu používat slovo „výraz“ pro Bühlerův Ausdruck.

8 Srov. (MUKǍ̌OVSKÝ 1983 [1938]: 57). Vztahu mezi lingvistickými funkcemi a literárními žánry se věnuje poněkud povrchně, přestože představují základní problém. Hlavním tématem tohoto článku je přidání estetické funkce k Bühlerovým třem funkcím.
} 
funkce jazyka, emoce a síla vůle v nich tedy převládá. Veltruský nepochybně tento názor nesdílí. ${ }^{9}$

Veltruský publikoval své názory na Bühlerovu teorii ve studii z roku 1985 „Bühlers Organon-Modell und die Semiotik der Kunst“ (Bühlerův Organon Model a sémiotika umění). V této práci kritizuje především tři další funkce, které k Bühlerovým třem základním přidal Roman Jakobson. ${ }^{10}$ Pro mne je však důležitější implicitní spor se Zichem a Mukařovským.

Veltruského shrnutí tří funkcí uvedených v díle Organon Model ukazuje potenciál monologu i dialogu v komunikaci. Uskutečnění jednoho či druhého potenciálu závisí na způsobu, jakým se mluvčí vyrovnává s výzvou. Může si bud’ přát, aby jeho partner převzal jeho myšlenky, nebo si přát, aby rozvinul myšlenky své. V prvním př́ípadě je výsledkem monolog, zatímco druhý případ otevírá dialog. Je proto na mluvčím, aby rozhodl, jestli se proces komunikace má stát monologem nebo dialogem.

Veltruský musí najít silnější argument ve prospěch dialogu. Ten zní přibližně takto: jestliže funkční systém ponechá rozhodnutí o monologu nebo dialogu na mluvčím, komunikace může být podřízena jeho osobním zájmům, zatímco zájem o poznání je potlačen. Takže se musí najít objektivní podklad, na němž mohou vzniknout pevné základy tohoto dvoustranného poznávacího procesu v komunikaci. Karl Bühler učí, že jazyk odkazuje na předměty za pomoci symbolických znaků podstatných jmen a ukazovacích znaků zájmen. Ukazovací znaky nemají žádný samostatný význam, pouze ukazují jakoby prstem na něco, co stojí mimo ně. Mezi zájmena v jazyce patří zájmeno první osoby já, zájmeno druhé osoby ty a třetí osoby to. Tato tři zájmena tvoří scénářr, když se zapojí do komunikace. ${ }^{11} J a ́$ a ty označují mluvčího a posluchače, zatímco to označuje předmět komunikace. Ve scénáři já a ty představují subjektivitu dvou lidských partnerů, zatímco to subjektivitu postrádá. Pokud je partner mluvčího zredukován na osobu, k níž se hovoří, ale nikoliv s níž se hovoří, zájmeno ty ztrácí znak subjektivity, takže se podobá zájmenu to. To je případ monologu. Aby to bylo ještě jasnější, můžeme si tato tři zájmena představit jako trojúhelník, v němž základnu tvoří já a ty, zatímco vrchol tvoří to. V monologu ztrácí zájmeno ty své místo na základně a přesouvá se na vrchol vedle zájmena třetí osoby to. Dá se tedy říci, že monologické žánry lyriky a epiky se zbavují poloviny strany trojúhelníku. Naproti tomu v dramatu se realizují strany obě.

Tento obraz jazyka, který jsem se zde snažila shrnout, umožňuje Veltruskému odmítnout Zichovo odvození dramatického žánru z epiky. Žádný monologický žánr nemůže

9 Aristoteles v Poetice rozlišuje tři typy dramatu: drama činu, povahy a myšlenky. Je zřejmé, že „myšlenka“ musí být vyjádřena jazykem. Aischylos, který uvedl dialog do dramatu, „považoval dialog za základ“ (ARISTOTELES 1979: 19). Aristoteles považuje drama myšlenky za nejméně důležité, drama činu za nejvyšší a drama povahy řadí mezi ně. Veltruský v tomto ohledu souhlasí spíše s Aischylem.

10 Jakobson představuje svůj model šesti funkcí ve své práci Lingvistika a poetika (1959). Čtvrtou funkci nazval poetickou, ta koresponduje s estetickou funkcí Mukařovského. Český termín pro sdělovací funkci (Darstellung u Bühlera) je poznávací funkce. Srov. (JAKOBSON 1995: 82).

11 Bühler pojednává o ukazovacích znacích v souvislosti s prostorem a časem. Viz odst. 7 „Die Origo des Zeigfeldes und ihre Markierung“ (BÜHLER 1978). Tyto aspekty ponechávám stranou, ačkoliv Veltruský se o ně velmi zajímá. „Scénář“ je ústředním termínem v sociální lingvistice Valetina Vološinova, k níž se Mukařovský i Veltruský často odvolávají. 
zplodit dialogický žánr. V antickém Řecku se drama vyvíjelo ve fázi, kdy diskuse o veřejných záležitostech vyžadovaly odpovídající veřejné fórum a formu. Již existující epické a lyrické žánry byly nedostačující kvůli jejich monologické stavbě. Platónovy filozofické dialogy se také zcela určitě staly impulzem k vytvoření dramatu. Díky svému deficitu připravily podle Veltruského dva monologické, a tudíž jednodušší žánry epiky a lyriky cestu složitějšímu dramatu. Studium historického vývoje dramatu pomohlo Veltruskému vyvrátit Mukařovského názor, že monolog a dialog jsou rovnocenné.

\section{Akce a reakce versus akce bez reakce}

V předchozí části jsem se snažila vysvětlit, jak Veltruský řešil Mukařovského dilema dramatického žánru a jak popíral Zichovo genetické odvození dramatu z epiky. Nyní chci ukázat, co je podle mého názoru Veltruského vlastní dilema.

Jak již bylo zmíněno, Mukařovský se přikláněl spíše k divadlu než k dramatu. Zvláště se zajímal o experimenty divadelní avantgardy během prvních třiceti let dvacátého století. Rovněž jsem poukázala na skutečnost, že Otakar Zich upřednostňoval realistické období před avantgardou. V roce 1940, krátce před obhajobou své práce Drama jako básnické dílo (1942), ${ }^{12}$ napsal Veltruský kritickou studii o avantgardě „Člověk a předmět na divadle“. Kritika je zřejmější ve chvíli, kdy ji porovnáme s jeho studií z roku 1984 o Bühlerově „Organon modelu. Člověk a předmět na divadle“, zejména pak v pasážích, v nichž popisuje, jak si v divadelním experimentu vyměňují herec a prvky scény své místo, takže člověk se mění na předmět a neživý předmět se stává živou bytostí. V článku o Bühlerovi, který byl vydán o více než třicet let později, analyzuje stejný jev z teoretického, či dokonce filozofického pohledu. Veltruský se obává, aby nedošlo k setření rozdílu mezi lidským subjektem a předmětem, což by mohlo zničit poznávací schopnosti dramatu. Témata, s nimiž se nyní musím potýkat, jsou poněkud komplikovanější, protože zahrnují analytické metody i teoretickou poetiku a estetiku.

Začnu nejjednodušším problémem. Souvisí s Mukařovského přístupem k avantgardě. Mukařovský ve svých studiích „Jevištní řeč v avantgardním divadle“ z roku 1937 a „K dnešnímu stavu teorie divadla“ z roku 1941 chválí rozšíření našich znalostí o teoretickém kódu a obohacení kombinatorních možností kódu jako osvobození od zděděných omezení a jako osvobození tvořivosti. Nedlouho poté, v roce 1945, se tón změnil. V článku „K umělecké situaci dnešního českého divadla“ Mukařovský popisuje nebezpečnou krizi v souvislosti se ztrátou hierarchického principu v divadle.

Existují dva aspekty hierarchického principu, které se během experimentů avantgardy vytratily. Jedním z nich je opuštění Aristotelovy teorie ,jednotného napětí úměrně stoupajícího k vrcholnému bodu a po něm srázně klesajícího“ (MUKAŘOVSKÝ 1966: 320). Druhým je úplná změna napětí: „hra stává se nepřetržitým pásmem napětí dílčích, z nichž každé dochází samostatného vyřešení a nenavazuje styku se sousedními“

12 Verzi studie „Čtení o jazyce a poesii“ z roku 1942, která byla cenzurována, Veltruský v roce 1977 upravil a přepsal pro anglické vydání pod názvem „Drama as Literature“. V roce 1999 byla studie vydána v češtině; doslov a komentář napsal Ivo Osolsobě. 
(MUKAŘOVSKÝ 1966: 320). Druhý aspekt je důsledkem prvního, ale nacházíme zde ještě něco jiného. Dříve Mukařovský myslel, že model akce a reakce avantgardního divadla se přesunul ze svého původního místa ve verbálním dialogu do vztahu mezi veškerými hmotnými prvky divadla. Tento přesun měl přinést nový typ dialogu, v němž je lidské slovo pouze jedním z mnoha prvků. Je však velmi nejisté, zda se tato, řekněme, juxtapozice prvků scény a světla může nazývat dialogem ve smyslu akce-reakce nebo ve vztahu mezi replikami. Kromě toho pouhá juxtapozice není hierarchickým principem, takže se nemůže stát konstruktivním principem uměleckého díla, které hierarchii vyžaduje. Ve svém článku z roku 1937 Mukařovský vyjádřil naději, že anti-hierarchický řetězec akce-reakce mezi různorodými hmotnými prvky přinese model rovnostářských kontaktů mezi členy demokratické společnosti mimo divadlo. Když politická situace v jeho zemi otřásla jeho nadějí, Mukařovský navrhl něco nového: model akce-reakce by měl být nahrazen řetězci akcí bez reakcí. Nositelem, a tudíž i iniciátorem nepřetržitých obnovených akcí by měl být herec na jevišti. Toto řešení znovu ustavilo nadřazenost lidského subjektu proti vládě předmětů, ale rovněž znamenalo opuštění dialogického principu v divadle a definitivní odtržení divadla od literárního dramatu.

V Mukařovského myšlení se objevuje několik problémů, například jeho (krátkodobé ${ }^{13}$ opuštění hierarchické struktury uměleckého díla. Přesto je podle mého názoru pravděpodobně největším problémem jeho přesvědčení, že aristotelské ,jednotné napětí“ se neodvolatelně ztratilo. Nyní se zastavím u problematiky tohoto „napětí“. Dovede nás $\mathrm{k}$ Veltruského neřešitelnému dilematu, zmíněnému výše, avšak ke sledování této cesty je zapotřebí trpělivosti.

Aristoteles ve své Poetice pojednává o dvou funkcích dramatické zápletky v porovnání s celou strukturou dramatického uměleckého díla. Zápletka definuje vztahy mezi začátkem, středem a koncem dramatu jako vztahy logické a kompoziční distribuce částí jako vztahy estetické. Tyto dvě funkce tak tvoří dvě různé konstruktivní úrovně, logickou a estetickou. Ruští formalisté tyto dvě úrovně nazvali fabula (zápletka) a sjužet ${ }^{14}$ (námět). Bohužel považovali logickou formu fabule za pasivní formu ve vztahu k aktivní formě sjužetu. Nevšimli si, že je to právě fabula, která předurčuje jednotu celého díla. Jejich chyba byla odpustitelná, nebot aplikovali analýzu fabuly a sjužetu pouze na epiku, kde se funkce zápletky řídí jinými principy než v dramatu. Naproti tomu velmi vlivná Hegelova estetika upřednostňovala drama, ostatně živý zájem o tento žánr můžeme pozorovat v průběhu celého devatenáctého století. Nyní budu svoji pozornost soustředit na dva teoretiky, Gustava Freytaga a Otakara Zicha.

V roce 1863 vydal německý dramatik Freytag práci Die Technik des Dramas (Technika dramatu). Jeho příspěvek k analýze dramatu je dvojí. Freytag, podobně jako Hegel, definoval zápletku jako kombinaci dvou základních složek, zvaných akce a reakce (Freytag dává přednost termínům Spiel und Gegenspiel / hra a protihra). Je důležité si uvědomit,

13 Mukařovský ve svém posledním článku o českém divadle „D34-D48 ve vývoji českého divadla“ schvaluje návrat Emila Františka Buriana k př́sně hierarchickému režisérskému divadlu. Dialogická osa již není uvnitř divadelní práce, ale mezi režisérem a diváky. Tento druh „dialogu“ se podobá propagandistickému monologu.

14 U nás se setkáme pouze s přepisem slova сюжет ve tvaru sujet nebo soudoběji syžet. Ve studii ponecháváme přepis slova, který použila v původním znění autorka studie. (pozn. red.) 
že na rozdíl od epické zápletky je počet částí dramatické zápletky striktně omezen pouze na dvě. Akce je vždy počáteční změnou (nebo pokusem o změnu) dané situace, po níž následuje reakce. Akce a reakce poskytují dvě místa pro umístění hlavních postav dramatu. Protagonista je umístěn do místa akce (první herec), antagonista do místa reakce (druhý herec). Hrdina hry je bud' protagonistou, který je pověřen akcí, nebo antagonistou, který je pověřen reakcí. Takže jsou zde dva možné typy dramatického hrdiny, počátečně aktivní nebo reaktivní (ve smyslu pasivní) hrdina. ${ }^{15} \mathrm{~K}$ tomu, že vůbec hovoříme o „hrdinovi“, nás nevede role nositele samotné akce nebo reakce, ale trvalé soustředění na jednoho ze dvou nositelů role během časového průběhu akce a reakce. Kromě tohoto nového přístupu k úrovni zápletky Freytag rovněž zkoumal úroveň kompozice. S odkazem na Aristotela definoval pět konstantních bodů na napětové křivce, kde první tři vedou postupně k vrcholu a poslední dvě označují pád a konečnou katastrofu (v tragédii). Rovněž přidal variabilní body, jako například zpomalení a zrychlení, které převzal z hudební kompozice.

Otakar Zich se více než Freytag zajímal o logický vztah mezi akcí a reakcí. Rozlišuje tři varianty: reakce se přizpůsobuje akci, nebo akci popírá, nebo jí protiřečí. Popisuje rovněž vnitřní strukturu lidského jednání jako vnitřní příčinný vztah mezi motivací a záměrem. Když se dvě jednání spojí jako v dramatickém modelu akce a reakce, jejich vnější příčinný vztah se dá analyzovat podle těchto třech logických vztahů. ${ }^{16}$

Freytagovy a Zichovy analytické nástroje se mohou navzájem kombinovat. Zichova typologie logických vztahů zápletky umožňuje analýzu klasických, realistických, a dokonce i moderních dramatických děl; Freytagova konstrukce dvou typů hrdinů je vhodná pro klasické i realistické drama a dá se aplikovat i na anti-hrdinu moderního dramatu, který zůstává zcela neaktivní, at̉ už se stane nositelem akce nebo reakce. Rozdíl mezi takovým případem a Mukařovského oddělením reakce od akce spočívá v tom, že v dramatu jsou logicky definovaná místa (neboli topoi) akce a reakce vždy přítomna bez ohledu na to, jak jsou vyplněna dramatickými činiteli. Kompozice dramatu se musí samozřejmě lišit od klasického aristotelovského typu, kdy akce a reakce odpovídá Zichovu prvnímu typu, tj. přizpůsobení reakce akci. ${ }^{17}$

Pokud jsou akce i reakce, chápané jako spárovaná místa (topoi), v dramatu vždy přítomné, pak jsou jejich logické a estetické funkce vždy přítomné i v celkové struktuře. Jejich ,jednotné napětí“, o němž hovoří Mukařovský, nemůže být v divadle potlačeno, pokud se inscenuje literární drama. Můžeme použít termín „konstruktivní princip“, který pro roli dramatické zápletky definoval ruský formalista Jurij Tyňanov. ${ }^{18}$ Takový

15 Rozlišení mezi aktivním a pasivním hrdinou je odvozeno od gramatických kategorií slovesa.

16 Tyto části Zichovy knihy nenašly u teoretiků Pražské školy téměř žádný ohlas. Dokonce ani Emil Volek (2013), který poukazuje na Husserlův anti-psychologický vliv na Zicha, si Zichovy logiky jednání nevšímá.

17 Zich považuje první případ „co do dramatického účinku nejméně intenzívní“ (ZICH 1986: 137). Krátce poté říká, že je zapotřebí třetí osoby, která jedná proti dalším dvěma, aby se vytvořilo dramatické napětí. To je ovšem v protikladu proti logické pravdě, že nižší stupeň napětí je stále napětí. Zvláště v moderním dramatu je to velmi významné. Veltruský popsal tyto Zichovy zkratky jako zjednodušení (VELTRUSKÝ 1994 [1981]: 16) ve prospěch realismu.

18 Tyňanov (1977 [1924]) rozlišuje mezi konstruktivním principem a konstruktivním faktorem. Tyto termíny by měly být brány v úvahu při diskusích o žánrech. Názor Jiř́iho Veltruského na literární druh jako jistou 
princip tvoří všechny části i momenty jakéhokoliv uměleckého díla. „Konstruktivní princip“ nemusí být nutně umístěn na nejnižší, materiální vrstvu, jak to předpokládali ruští formalisté i pražští strukturalisté. Může být rovněž umístěn na vyšší, abstraktnější vrstvu dramatické zápletky. Takový předpoklad odporuje Mukařovského analytické metodě literárního uměleckého díla, které dal jméno sémantické gesto. Jiř́i Veltruský ve své studii z roku 1942 „Drama jako básnické dílo“ aplikoval tuto metodu na dramatický žánr. Veltruského studie předkládá pro analýzu dramatického dialogu velmi hodnotné nástroje, které však mají malé využití pro definici dramatické zápletky a kompozice. Možná se mýlím, ale zdá se mi, že Veltruský se nikdy neosvobodil od určitého druhu dogmatu, který je obsažen v pojmu a metodě sémantického gesta. Gesto vychází z předpokladu, že poetické jevy v různých vrstvách uměleckého díla tvoří „dominanta“, která je umístěna v nejnižší, materiální vrstvě. Gesto tak vytváří poetickou strukturu zespoda nahoru. Opačný směr, odshora dolů, zde není brán v úvahu.

Rozlišování Edmunda Husserla mezi „einseitige Fundierung“ a „wechselseitige Fundierung“ (jednostranný základ, oboustranný základ) nám umožňuje charakterizovat sémantické gesto jako myšlení pouze v termínech „einseitige Fundierung“. „Wechselseitige Fundierung" by možná vyřešilo Veltruského dilema spočívající v nemožnosti jednostranného odvození horní vrstvy dramatu od vrstvy nižší. ${ }^{19}$ Filozof Oleg Sus svého času navrhl, aby umělecké dílo mělo dvě dominanty (SUS 1996 [1968] a 1981). Pokud vím, o této myšlence čeští strukturalisté nikdy nediskutovali. K Susovu návrhu by rovněž byla zapotřebí diskuse o konstruktivnim principu a o dominantě. Tato diskuse by mohla probíhat následujícím způsobem: Aristotelova myšlenka zápletky, jejíz funkce definuje základní části celého dramatu (začátek, střed, konec), spojená s Freytagovými a Zichovými objevy vnitřních variant, představuje konstruktivni princip dramatu, zatímco podle závěrů Mukařovského a Veltruského v souvislosti s dialogem je dominanta definována na lingvistické úrovni. Veltruský se k tomuto názoru přiblížil ve své práci Drama jako básnické dílo, kde při definování dramatu předkládá dvě tvrzení: zaprvé, drama je „co do jazyka básnictvím dialogu, [...] drama je co do děje jednáním. [...] Větší oprávněnost má ovšem označení dramatu jako básnictví dialogu, protože vyjadřuje specifický ráz jeho významové výstavby, že něhož vyplývá celá jeho struktura, a tedy i okolnost, že dramatický děj má podobu jednání.“ Druhé tvrzení říká: „[...] dialog je v dramatu toliko dominantním jazykovým útvarem.“ (VELTRUSKÝ 1999 [1942]: 93) Kontradikce mezi těmito dvěma tvrzeními potvrzuje Veltruského nevyřešené dilema.

\footnotetext{
ideální formu, „která nepodléhá proměnám v čase a konkrétními díly různých básníků je jen s větší či menší dokonalostí ztělesňována“ by mohl najít oporu v Tyňanovského teorii. Mimochodem, citovaná pasáž Veltruského (1999 [1942]: 8) se liší od české verze z roku 1942, kde se cenzuře pravděpodobně nelíbil výraz ideálni forma a byl povolen pouze termín nadčasovost (VELTRUSKÝ 1942: 404).

19 Edmund Husserl diskutuje o různých formách základu ve svém díle Logische Untersuchungen. Tato otázka souvisí s problémem částí a celků. Pro literární studia (o nichž se Husserl nezmiňuje) by mohl být zvláště důležitý sled základů od nižších k vyšším částem, tzv. Stufenfolge a relativní nezávislost abstraktních částí (motivů a témat v literatuře) na materiálních částech (HUSSERL 1992: 267ff).
} 


\section{Veltruského pokus o provázání dramatu a divadla}

Veltruského pokus o provázání dramatu a divadla je mnohem více motivován jeho zájmem o situaci divadla než o situaci dramatu. Drama jako literární druh nepotřebuje divadlo, ale divadlo bez dramatu je „pokřivené““. ${ }^{20}$ Toto je jasné stanovisko proti Mukařovského návrhu řešit krizi divadla zřetelným oddělením obou umění, a podobně je to odmítnutí Zichova názoru, že psané drama je závislé na divadelním představení.

Pozice Veltruského a Mukařovského jsou poznamenány odlišnými časovými horizonty. Zatímco Mukařovský se soustředí na škody, které divadlu způsobila avantgarda, Veltruský se vrací zpět $\mathrm{k}$ momentu oddělení divadla od dramatu, k němuž začalo docházet již koncem devatenáctého století. Otakar Zich byl v tomto směru užitečný, nebot znovu včlenil psané drama do struktury divadla, zatímco jiní teoretikové propagovali vyloučení dramatu. Ale Veltruský nemůže přijmout Zichův způsob znovuzačlenění dramatu. Nesouhlasí se Zichem především v názoru na úlohu dialogu.

Mám dojem, že podle Zichova mínění není dialog, který napsal autor textu, nejnižším základem dramatického divadla; tento základ spíše umistuje do fyzického divadelního prostoru. Podle Zicha samotný herec na jevišti nemůže nikdy vytvářet dramatické divadlo, $\mathrm{k}$ tomu jsou zapotřebí alespoň dva herci. ${ }^{21}$ Jejich těla jsou středy energetických sil v energetickém prostorovém poli; jejich pohyby utvářejí pole za pomoci dynamické paralely nebo kontrastujících replik. Protože Zich trvá na alespoň dvou hercích na jevišti, zaručuje zároveň, že bipolární forma prostorové vrstvy se znovu objeví podle zákona strukturní shody v dialogu a v zápletce. Tím se vysvětluje, proč divadlo inklinuje silněji $\mathrm{k}$ dramatickému textu než $\mathrm{k}$ epice a lyrice, přestože v některých jeho vývojových etapách převládaly lyrické nebo epické tendence.

Když Zich tvrdí, že divadlo předkládá aspekty dramatického textu, které psaný text nedokáže odhalit, zjevně má na mysli prostorovou formu, v níž - jak bylo řečeno musí být př́itomni alespoň dva herci. Řečové akty herců nejsou plnohodnotné řečové akty, protože formulace s jejím významem patři dramatickým postavám, a nikoli hercům. Zich odlišuje fyzické mluvení herců od promluv dramatických postav. V tomto ohledu má samožrejmě pravdu, což Veltruský nepopíral. Zich ale také tvrdí, že fyzický řečový akt vytváří fyzické napětí (paralelně k jejich tělesnému napětí), které v psaném dialogu není obsaženo. Tato dodatečná napětí mají na diváka zvláštní vliv, který čtenář dramatického textu nezná. V tomto bodě spočívá základní nesouhlas Veltruského se Zichovou estetikou.

Zichova experimentální estetika spočívá v izolování jednotlivých prvků ze strukturálního celku s cílem ověřit jejich bezprostřední účinek na diváka v divadle. Tato metoda je nejpatrnější v Zichově teorii, kterou Sus nazývá presémiotickým modelem herce. Zich rozlišuje mezi hercem, hereckou postavou a dramatickou osobou. Tyto tři aspekty

20 Srov. (VELTRUSKÝ 1994: 98). Souhrn celé Veltruského teorie můžete najít v jeho sbírce materiálů pro plánovanou knihu z roku 1996. Viz také přepracované vydání knihy z roku 2012, kterou připravila Jarmila F. Veltrusky.

21 Toto vylučuje tzv. monodrama s jedním hercem z pravého divadelního dramatu, jak jej vnímá Zich. Podle Veltruského je monolog v dramatu variantou dialogu. 
se dají porovnat s materiálem (signans) a znakem (signatum). Zich uvádí do vzájemného vztahu tyto tři faktory s třemi účinky na diváka: herec je vnímán jako živá osoba, př́itomná ve stejném fyzickém prostoru jako divák; divák interpretuje herecké vytváření jevištní postavy prostř̌ednictvím kostýmu, mimiky, gest a pronášení slov jako „technickou významovou představu“; vtělenou dramatickou postavu vnímá jako významovou představu obrazovou. První a druhý účinek může nastat pouze v divadle. Zich je nazývá motorické reakce. Trvá na tom, že tento druh reakcí, rovněž označovaných jako dramatické napětí, se nesmí zaměňovat s napětím vyvolaným očekáváním..$^{22}$ Dramatické napětí tak znamená bezprostřední tělesnou komunikaci mezi hercem (herci) na jevišti a diváky ve smyslu stimulu a reakce. Skrze ně se má završit estetické uskutečnění, které doplňuje psaný text dramatu.

Ani metoda párování izolovaných prvků s izolovanými reakcemi vnímatele, ani budování uměleckého díla na bezprostředních tělesných účincích ve smyslu stimulu a reakce není pro pražský strukturalismus přijatelná. Estetika této školy pokračuje v Aristotelově estetice odstupu vyjádřené $\mathrm{v}$ jeho teorii katarze. Tato známá teorie předpokládá divákův přehled o celém díle. Během procesu vnímání umožňuje tento přehled logické a formální očekávání, které v průběhu vnímání nachází částečné, a na konci dokonalé naplnění. Filozof kritizuje herce, kteří přehrávají své role ve snaze přitáhnout pozornost diváků a vysloužit si u nich potlesk. Kvůli tomuto vulgárnímu kontaktu mezi herci a diváky dával Aristoteles přednost četbě dramatu před sledováním divadelního představení. ${ }^{23}$

Opustím Veltruského zjevný estetický „aristotelismus“ a místo toho se budu soustředit na dva poetické aspekty. První z nich se zabývá ztrátami divadla, které jsou způsobeny oddělením od psaného dramatu, druhý se týká Veltruského původní analýzy tzv. hlavního textu (Haupttext) a vedlejšího textu (Nebentext) v dramatu.

Ztráty divadla jsou ztráty v oblasti intelektuálních schopností a umělecké vytříbenosti. Systém jazyka je intelektuálně nadřazen všem ostatním znakovým systémům. Díky prastaré symbióze dramatu a divadla se všechna neliterární umění používaná v divadle rovněž intelektualizovala, takže mohou převzít funkce verbálního znaku. Existuje jedna vynikající Mukařovského studie z jeho raného období, v níž analyzuje, za jakých podmínek by gesto umístěné do dominantní pozice mohlo převzít funkce verbálního znaku. Tuto studii nazval „Pokus o strukturní rozbor hereckého zjevu: Chaplin ve Světlech velkoměsta“ (1931, do angličtiny přeloženo v roce 1978) a soustředí se v ní na herce v němém filmu; platí však i pro herce divadelního. Podmínkou dominance nonverbálních znaků je naprosté potlačení verbálního znaku: „Slovo, které je nejvíce s to, aby ovlivňovalo gesta, musí být úplně potlačeno, majíli se gesta uplatnit jako složka dominující.“ (MUKAŘOVSKÝ 2000: 465) Veltruský by zajisté Mukařovského analýzu schválil. Verbální znak kromě obecných intelektuálních schopností rovněž převádí poetickou

22 Srov. (ZICH 1986: 40). Napětí vyvolané logickými nebo kompozičními modely akce-reakce na úrovni dialogu nebo zápletky je tak vyčleněno ze Zichova materialistického pojetí dramatického napětí. Na druhé straně však uznává specifické napětí patřící k dialogu a zápletce.

23 Srov. (ARISTOTELES 1979: 29, 107). Na straně 109 říká, že tragedie „i bez představení dosahuje svého cíle [...]; nebot pouhým čtením se jeví, jak jest.“ 
vytříbenost do uměleckého projevu herce. Veltruský tyto aspekty pečlivě propracoval v několika studiích. ${ }^{24}$ Symbióza mezi dramatem a divadlem tak obzvláště pozdvihla herecké umění.

O otázce vztahu mezi hlavním textem a vedlejším textem diskutovali mnozí teoretici. ${ }^{25}$ Veltruského původním příspěvkem je kategorie subjektu, v jejímž rámci rozlišuje mezi autorovým ústředním subjektem celého díla a mezi subjekty dramatických postav, které jsou pouze částmi díla. Ze všezahrnujícího hlediska ústředního subjektu jsou dva různé druhy textu, hlavní text a vedlejší text, neustále navzájem propojeny. Čtenář je vyzván, aby se k tomuto ústřednímu hledisku připojil, což mu umožní sledovat odvíjení dramatu ve všech fázích a ve všech vrstvách s odstupem, jaký vyžaduje Aristotelova katarze. Z hlediska lingvistiky by člověk mohl tento vztah mezi autorem a čtenářem nazvat monologem. Ale tento termín není zcela přiměřený, protože dramatický autor (který má být vždy vnímán jako ústřední subjekt díla) nemůže přímo oslovit čtenáře. Pravdivým vztahem je spíše úkon předvádění na straně autora a úkon vnímání na straně čtenář̀e.

Veltruský odvozuje dva typy dramatu od variabilního vztahu mezi ústředním subjektem autora a mezi subjekty dramatických postav. V prvním typu vystupuje do popředí více subjekt autora, v druhém typu zůstává skrytý za subjekty dramatických postav. Tato typologie je velmi užitečná při analýze všech druhů dramatických textů. ${ }^{26} \mathrm{~V}$ diskuzi o tezi Otakara Zicha, týkající se neúplnosti literárního dramatu a o jeho závislosti na divadle, trvá Veltruský na tom, že literární drama se stává nezávislým na divadle díky vzájemnému vztahu mezi hlavním a vedlejším textem. Závislost existuje ve druhé rovině: divadlo bez literárního dramatu nutně upadá, a to jak po intelektuální, tak po estetické stránce.

\section{Bibliografie}

ARISTOTELES. 1979. Poetik. Griechisch und Deutsch. Leipzig: Reclam, 1979.

BÜHLER, Karl. 1978 [1931]. Sprachtheorie. Die Darstellungsfunktion der Sprache. Stuttgart: Fischer, 1978.

FREYTAG, Gustav. 1992 [1863]. Die Technik des Dramas. Darmstadt: Wissenschaftliche Buchgesellschaft, 1992.

HUSSERL, Edmund. 1992. Logische Untersuchungen. Untersuchungen zur Phänomenologie und Theorie der Erkenntnis. Vol. 2, Part 2. Hamburg: Felix Meiner, 1992.

24 Viz také (VELTRUSKÝ 1994 [1941-1976]), kde popisuje strukturální účinky jednotlivých verbálních prvků, jako jsou rytmus, intonace atd., v dominantní pozici. Rok 1941 pravděpodobně označuje pokračování této studie v textu Drama jako básnické dílo, vydaného v roce 1942, ale dokončeného v roce 1941.

25 Roman Ingarden (1931) prosazoval termíny Haupttext a Nebentext, které se dnes používají v teorii dramatu i divadla. V nedávné době se touto tématu věnuje Manfred Pfister (1988).

26 Tuto typologii již rozvinul Veltruský (1942). Pokusila jsem se aplikovat Veltruského typologii na texty z jiných období a publikované v jiných jazycích (SCHMID 1992). 
INGARDEN, Roman. 1965 [1931]. Das literarische Kunstwerk mit einem Anhang von den Funktionen der Sprache im Theaterschauspiel. Tübingen: Niemeyer, 1965.

JAKOBSON, Roman. 1995 [1959]. Lingvistika a poetika [Lingvistics and Poetics]. In id. Poetická funkce [Poetic Function]. Jinočany: Nakladatelství H\&H, 1995: 74-105.

MUKǍ̌OVSKÝ, Jan. 1977 [1948]. D34-D48 ve vývoji českého divadla [D34-D48 in the Development of the Czech Theatre]. In id. Studie z estetiky [Studies From the Aesthetics]. Praha: Odeon, 1977: 458-460.

MUKAŘOVSKÝ, Jan. 1977 [1941]. K dnešnímu stavu teorie divadla [On the Present State of the Theory of Theatre]. In id. Studie z estetiky [Studies From the Aesthetics]. Praha: Odeon, 1977: 223-236.

MUKAŘOVSKÝ, Jan. 1977 [1945]. K umělecké situaci dnešního českého divadla [On the Artistic Situation of the Present Czech Theatre]. In id. Studie z estetiky [Studies From the Aesthetics]. Praha: Odeon, 1977: 447-458.

MUKǍ̌OVSKÝ, Jan. 1977 [1931]. Pokus o rozbor hereckého zjevu: Chaplin ve Světlech velkoměsta. In id. Studie z estetiky [Studies From the Aesthetics]. Praha: Odeon, 1977: 254-259; English version 1978: An Attempt at a Structural Analysis of a Dramatic Figure. In John Burbank and Peter Steiner (překl. a ed.). Structure, Sign, and Function Selected Essays by Jan Mukařouský. New Haven/London: Yale University Press, 1978: 171-177.

MUKǍ̌OVSKÝ, Jan. 1982 [1938]. Básnické pojmenování a estetická funkce jazyka [Poetic Appellation and the Aesthetic Function of Language]. In id. Studie z poetiky [Studies From the Poetics]. Praha: Odeon, 1982: 55-60.

MUKAŘOVSKÝ, Jan. 1982 [1940a]. Dialog a monolog [Dialogue and Monologue]. In id. Studie z poetiky [Studies From the Poetics]. Praha: Odeon, 1982: 208-229.

MUKAŘOVSKÝ, Jan. 1982 [1940b]. O jazyce básnickém [On Poetic Language]. In id. Studie z poetiky [Studies From the Poetics]. Praha: Odeon, 1982: 93-136.

MUKǍ̌OVSKÝ, Jan. 2000. Studie I. Brno: Host, 2000.

PFISTER, Manfred. 1988. Das Drama Theorie und Analyse. Munich: Wilhelm Fink, 1988.

PROCHÁZKA, Miroslav. 1994. Komparativní sémiotika Jiřího Veltruského [Comparative Semiotics of Jiří Veltruský]. In Jiří Veltruský. Př́spě̃uky $k$ teorii divadla [Contributions to the Theory of Theatre]. Praha: Divadelní ústav, 1994: 5-12.

SCHMID, Herta. 1992. Bachtins Dialogizitätstheorie im Spiegel der dramatisch-theatralischen Gattungen. In Herta Schmid and Jurij Striedter (edd.). Dramatische und theatralische Kommunikation. Beiträge zur Geschichte und Theorie des Dramas und Theaters im 20. Jahrhundert. Tübingen: Gunter Narr, 1992: 36-90.

SCHMID, Herta. 1997. Jiří Veltruský's Vermächtnis an die Theaterwissenschaft. Balagan Slavisches Drama, Theater und Kino 2 (1997): 3: 79-111.

SUS, Oleg. 1981. Individuum - Struktur - Anthropologische Konstante (Randbemerkungen zur Beziehung zwischen dem Strukturalismus und der ästhetisch-semiologischen Anthropologie). In Peter Zima (ed.). Semiotics and Dialectics Ideology and the Text. Amsterdam: John Benjamins Publishing Company, 1981: 243-281.

SUS, Oleg. 1996 [1968]. Konec „dobrého tvaru“ (O nestrukturnosti struktury) [The End of a „Good Form“ (On the Non-Structuredness of Structure)]. In id. Bez boh i geneze? [Genesis Without Gods?]. Brno: Vetus via, 1996: 45-55. 
TYŇANOV, Jurij. 1977 [1924]. Das Problem der Verssprache: Zur Semantik des poetischen Textes [The Problem of Poetic Language: On the Semantics of Poetic Texts]. Překlad z ruského originálu, úvod a index Inge Paulmann [Transl. from a Russian original, introd. and index by Inge Paulmann]. Munich: Wilhelm Fink, 1977.

VELTRUSKÝ, Jiří. 1942. Drama jako básnické dílo [Drama as a Poetic Work]. In Bohuslav Havránek and Jan Mukařovský (edd.). Čteni o jazyce a poesii [Reader in Language and Poetry]. Praha: Družstevní práce, 1942: 403-502.

VELTRUSKÝ, Jiří. 1977. Drama as Literature. Lisse: Peter de Ridder, 1977.

VELTRUSKÝ, Jiří. 1984. Bühlers Organon-Modell und die Semiotik der Kunst. In Achim Eschbach (ed.). Bühler-Studien I. Frankfurt: Suhrkamp, 1984: 161-205.

VELTRUSKÝ, Jiří. 1985. Drama as Literature and Performance. In Erika Fischer-Lichte (ed.). Das Drama und seine Inszenierung. Tübingen: Niemeyer, 1985: 12-21; Český překlad 1995: Drama jako literární dílo a představení. In id. Př́spěvky k teorii divadla [Contributions to the Theory of Theatre]. Praha: Divadelní ústav, 1994: 95-101.

VELTRUSKÝ, Jiří. 1994 [1940]. Člověk a předmět na divadle [Man and Object in the Theatre]. In id. Př́spě̀vky k teorii divadla [Contributions to the Theory of Theatre]. Praha: Divadelní ústav, 1994: 43-50.

VELTRUSKÝ, Jiří. 1994 [1941-1976]. Dramatický text jako součást divadla [Dramatic Text as a Component of Theatre]. In id. Př́spěveky $k$ teorii divadla [Contributions to the Theory of Theatre]. Praha: Divadelní ústav, 1994: 77-94.

VELTRUSKÝ, Jiří. 1994 [1981]. Divadelní teorie Pražské školy [Theatre Theories of the Prague School]. In id. Př́spě́vky k teorii divadla [Contributions to the Theory of Theatre]. Praha: Divadelní ústav, 1994: 15-24.

VELTRUSKÝ, Jiří. 1996. Esquisse d'une sémiologie du théâtre. Degrés Revue de synthèse à orientation sémiologique 24 (1996): 85/86 : c1-c172.

VELTRUSKÝ, Jiří. 1999. Drama jako básnické dílo [Drama as Literature]. Brno: Host, 1999.

VELTRUSKÝ, Jiří. 2012. An Approach to the Semiotics of the Theatre. Reconstructed, translated into English and prefaced by Jarmila Veltrusky. Travaux du Cercle linguistique de Prague, Brno: Masarykova univerzita, 2012.

VOLEK, Emil. 2013. Introducción [Introduction]. In Jarmila Jandová a id. (překl. a edd.). Teoría teatral de la Escuela de Praga: de la fenomenología a la semiótica performativa [The Prague School Theory of Theatre: From phenomenology to performance semiotics]. Madrid: U. nacional de Colombia, 2013: 27-36.

WALZEL, Oskar. 1968 [1926]. Shakespeares dramatische Baukunst. In id. Das Wortkunstwerk. Mittel seiner Erforschung. Darmstadt: Wissenschaftliche Buchgesellschaft, 1968: 302-325.

ZICH, Otakar. 1986 [1931]. Estetika dramatického uměni. Teoretická dramaturgie [Aesthetics of the Dramatic Art. A Theoretical Dramaturgy]. Praha: Panorama, 1986. 


\section{Summary}

\section{Jiři Veltruský Revisited}

The article deals with Jiří Veltruskýs ideas about the relation between the literary drama and the theatre. Veltruský speaks in favour of a reunion between both art kinds, whose theoretical and institutional separation began in the late nineteenth century. Arguing that the theatre suffers intellectually and aesthetically from the separation Veltruský refers to Jan Mukařovskýs studies on the dialogue. His main opponent is Otakar Zich, who considered the written drama a mere component of the theatre. The article shows also that in Zich's and Gustav Freytag's theories one can find logical and poetical models of the dramatic plot valuable until today, yet neglected by the Prague School and by Veltruský too.

\section{Klíčová slova}

drama jako literární žánr, logické strukturování dramatického děje, některé problémy teorie dominance, znovuobnovení svazku divadla a dramatu, dva typy dramatu podle Veltruského

\section{Keywords}

drama as a literary genre, logical structures of the dramatic plot, problems of the dominant theory, reunion of drama and theatre, Veltruskýs two types of the literary drama

DOI: $10.5817 /$ TY2016-1-6

Herta Schmid (herta-schmid@hotmail.com) se zabývá slovanskými literaturami (především ruskou, polskou a českou literaturou), teorií a analýzou divadla a dramatu a teorií literatury (ruským formalismem a pražským strukturalismem). Studovala němčinu, ruštinu a další slovanské jazyky a filozofii na univerzitě v Kolíně nad Rýnem, Bochumi a Praze. Doktorát získala v Bochumi za disertační práci o ruském dramatu (téma Anton Pavlovič Čechov), habilitovala se na Univerzitě v Kostnici prací o ruské povídce (zejm. se věnovala dílům Puškina, Gogola a Čechova). Místo výzkumného asistenta (Assistant Professor) získala v Semináŕi slovanských jazyků a literatur na Univerzitě v Bochumi a Amsterdamu, profesorské místo pak v semináři slovanských jazyků a literatur na univerzitě v Mnichově, na Ústavu divadelních studií na Univerzitě v Amsterdamu a ve Slovanském semináři na Univerzitě v Postupimi. Do důchodu odešla v roce 2008. Její nedávné významné publikace zahrnují studie ve sborníku Čechovs Tatjana Repina: Analyse und Umfeld eines verkannten Meisterwerks (Čechovova Tatjana Repina: Analýza a kontext nepochopeného mistrovského díla; Munich: Otto Sagner, 2006; edd. Jenny Stellemanová a Herta Schmid); Struktury a funkce. Výbor ze studii 1989-2009 (Praha: Karolinum, 2011); a články v kolektivní monografii Lermontov neu bewertet (Lermontov nově viděný; Munich/Berlin/Washington, D.C.: Otto Sagner, 2013; edd. Herta Schmid a Jenny Stellemanová). 
Herta Schmid (herta-schmid@hotmail.com) has been active in the following fields of academic teaching and research: Slavic literatures (Russian, Polish, Czech), theory and analysis of drama and theatre, and theory of literature (Russian Formalism, Prague Structuralism). She studied German, Russian and other Slavic languages, and philosophy at universities in Cologne, Bochum, and Prague. Her dissertation was on Russian drama (A. P. Chekhov) in Bochum, her habilitation on Russian stories (Pushkin, Gogol, Chekhov) in Konstanz. She was an Assistant Professor) at the Slavic Seminar in Bochum and Amsterdam, Professor at the Slavic Seminar in Munich, Professor at the Theatre Department in Amsterdam, and Professor at the Slavic Seminar in Potsdam. She retired in 2008. Her recent major publications include: articles in the volume Čechovs Tatjana Repina: Analyse und Umfeld eines verkannten Meisterwerks (Chekhov's Tatyana Repina: an analysis and context of a misunderstood masterpiece), eds. Jenny Stelleman and Herta Schmid, Munich: Verlag Otto Sagner, 2006; Herta Schmidová, Struktury a funkce. Výbor ze studii 1989-2009 (Structures and Functions. A selection of studies 1989-2009), Praha: Karolinum, 2011; articles in the volume Lermontov neu bewertet (Lermontov Revisited), eds. Herta Schmid and Jenny Stelleman, Munich/ Berlin/Washington, D.C.: Verlag Otto Sagner, 2013. 